\title{
$\mathbf{R}$ (on the application of Rudewicz) $\mathbf{v}$ Secretary of State for Justice
}

Court of Appeal: Lord Neuberger MR, Stanley Burnton and McFarlane LJJ, April 2012

Exhumation - ECHR - freedom of religion - family life

An application had been made for judicial review of the Home Secretary's decision to permit the exhumation and re-interment of the remains of Father Jarzebowski, a Polish Marian Father who had been instrumental in founding a school at Fawley Court, where he was buried. The Fathers, supported by the local bishop, wanted to reinter his remains with those of his fellow Marian priests at Fairmile Cemetery, where his grave would be publicly accessible - which at Fawley Court it was not. Counsel for Ms Rudewicz relied on the general presumption of permanence of burial enunciated by the Court of Arches in Re Blagdon Cemetery [2002] Fam 299; and argued that it was illogical for the Secretary of State to have relied on the desire of people to visit Father Jarzebowski's grave, since a large number of the objectors had expressly referred to their desire to visit his existing grave in situ and no-one appeared to have written in support of the proposal to exhume and rebury. It was also argued for Ms Rudewicz that, as the priest's nearest relative, exhumation would violate her rights under Article 8 (family life) and Article 9 ECHR (thought, conscience and religion). The Divisional Court had upheld the decision to allow exhumation. The Court of Appeal held that the decision of the Divisional Court had been neither irrational nor disproportionate. Moreover, the approach of consistory courts to faculties for exhumation did not apply to the grant by the Secretary of State of licences under section 25(ii) of the Burial Act 1857: the reasons for the general presumption of permanence in Blagdon was based on the theology of burial, which was not relevant to secular applications. In human rights terms, the decision had been proportionate. As to Article 8, the Divisional Court had dismissed that argument on the grounds, inter alia, that family life could not subsist after death. The Court of Appeal took the view that the wishes of the Provincial Superior had to be set against those of Ms Rudewicz, since in many ways he had the stronger case for being treated as Father Jarzebowski's closest family member. As to Article 9, the religious concerns of Ms Rudewicz and the objectors had to be balanced against those whose religious beliefs appeared to favour the grant of the licence. The appeal was dismissed. [Frank Cranmer]

doi:10.1017/So956618X12000646

\section{Sturt v Farran}

New South Wales Supreme Court: Sackar J, April 2012 Clergy - employment status

The plaintiffs were clergy in the Diocese of Newcastle against whom allegations of sexual misconduct had been made. After a hearing at which the plaintiffs 
chose not to appear, the diocesan Professional Standards Board recommended to the bishop that the plaintiffs be deposed from holy orders. Before the bishop could act on the recommendation, the plaintiffs commenced proceedings in the New South Wales Supreme Court alleging procedural unfairness and claiming, inter alia, that they were entitled to bring proceedings in the Supreme Court because they were seeking to protect rights as employees or rights accrued under a consensual compact that constituted the basis for their offices as clergy. The court acknowledged the long-held view that clergy were office-holders rather than employees. It was held, however, that the mere fact that the plaintiffs were clergy did not entitle the court to proceed upon a presumption that no contract of employment existed. The court acknowledged the importance of the issue of control. Although the plaintiffs had clear terms setting out their remuneration and holiday entitlements, there was no evidence from which the court could gauge what, if any, level of control or supervision was exercised over them. There was no adequate evidence to support the contention that the plaintiffs performed their roles pursuant to a contract of employment. Further, there were no contractual rights arising out of the National Constitution on which the plaintiffs could rely to invoke the court's jurisdiction. Contractual rights making the plaintiffs' claims justiciable did arise out of the Professional Standards Ordinance passed by the diocesan synod, which set down the procedure for dealing with allegations of sexual misconduct, although the allegations of procedural unfairness made by the plaintiffs were not substantiated. The proceedings were dismissed. [RA]

doi:10.1017/So956618X12000658

\author{
Re Holy Trinity, Hurstpierpoint \\ Chichester Consistory Court: Hill Ch, April 2012 \\ Re-ordering - incumbent - vacancy
}

A number of parishioners objected to the granting of a petition for the substan-

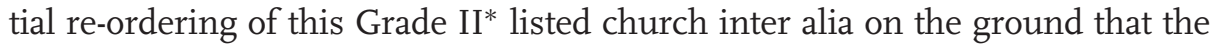
project should be reconsidered after the imminent retirement of the current incumbent. In granting the faculty, the chancellor rejected this ground, stating that, although the incumbent was the chairman on the PCC, the paradigm in every parish is collaborative ministry. He did not consider that the forthcoming vacancy and the appointment of a new incumbent was a valid or relevant consideration. $[\mathrm{RA}]$ 